\title{
THE HISTORICAL MEDICAL MUSEUM.
}

As has been already noted in these columns, the His torical Medical Museum which Mr. H. S. Wellcome has been preparing for a long time past has now come into being; and a very wonderful place it is. With his own extensive collections, and the assistance of a host of exhibitors of articles on loan, Mr. Wellcome has produced an exhibition of interesting objects bearing on every aspect of ancient and mediæval and modern medicine. To mention even a fractional percentage of the treasures now housed at $54 \mathrm{~A}$ Wigmore Street would involve a small catalogue in itself.

Many of the exhibits have, as is natural, an interest mainly medical; others appeal to all sorts and conditions of men; and others, again, have an especial institutional significance. First and foremost among the latter may be mentioned the (reconstruction of an) Italian hospital ward of the sixteenth century. The small room shown has no windows, though whether this is intended to represent faithfully an original remains in doubt. Apart from this, the scene shown might almost stand for the twentieth century instead of the sixteenth; for there are still plenty of hospitals in Italy, Spain, and other Mediterranean countries in which no higher standard of hospital construction' and equipment has yet been reached. The sixteenth-century lying-in room is another interesting reconstruction of distinctly realistic conception. The figures of the baby and its attendant are, perhaps, the most carefully carried out.

A fifteenth-century alchemist's laboratory, fully equipped with original apparatus and appliances of the period and with models of the actual furnaces used by those mediæval magicians, is perhaps of more general than particularly institutional interest; but it is a most fascinating exhibit, complete even to the stuffed crocodile which was an indispensable adjunct of any high-class alchemist's establishment. The hospital pharmacy of the sixteenth century is chiefly noticeable for the splendid collection of pottery which it contains. Another fine exhibit of this type is the eighteenth-century London pharmacy, containing the actual original shop-front of the first Bell, founder of the Pharmaceutical Society, and of the business which, after amalgamations and removals; is now carried on in Wigmore Street a few yards from Mr. Wellcome's museum. The vases and ewers of this shop are of Davenport ware, the ointment jars of Stafford: shire stoneware, and the essence bottles of red Venetian glass. Connoisseurs of these branches of art will find this shop well worth a visit.

The relics of various heroes of bygone days are interesting, not merely by reason of their illustrious owners, but because they also serve to show the state of contemporary medical and surgical progress. Thus Nelson's medicine chest on the Victory, Livingstone's pocket instrumentcase, Wellington's Peninsular War medicine-chest, and similar exhibits are certain to be sought out by visitors.

The paintings and prints are very numerous, and many of them represent persons prominent in the institutional world in their day. Probably the representations of Miss Nightingale will attract most attention from hospital workers of the present day; though Lord Lister's portraits may run them close. Of hospital worthies of more remote times there is a plentiful supply, including John Hunter, Abernethy, Brodie, Cooper, Jenner, and many others. Compared with the pictures of old-time medical practice and methods, there are not very many pictures of mediæval hospitals. One represents a scene at a hospital for incurables; another a surgical operation in $a$ seventeenth-century hospital ward; and there are others. But, broadly speaking, this part of the exhibition does not attain a high level of purely institutional interest. Finally, it is a great pleasure to acknowledge the courtesy with which our representative was received and shown round this unique and extremely interesting collection.

\section{THE INSTITUTIONAL LIBRARY.}

Babies. By Margaret French. (London: Macmillan and Co. 1913. Pp. 80. Price 1s. net.)

We have referred once or twice already to the extraordinary output of new books on babyhood during the last eighteen months; and several of the newcomers have seemed to us little likely to compete successfully with some of the others. This booklet, however, is decidedly not in that class. For one thing, it is addressed to maternity nurses, not to young mothers; and thus caters for a rather different public from most of the recent baby text-books. For another, it is written out of the fulness of a ripe experience, as anyone can see who troubles to read two or three pages. Briefly, the book is packed full of practical lore such as a maternity nurse might take a lifetime in picking up for herself : common sense is the keynote all through. The sections dealing with the abnormal baby are perhaps a shade less good than those upon the management of the normal infant; but, after all, if every nurse followed Miss French's hints, abnormal babies would be uncommon. If we had to select one chapter rather than another for especial praise, we think perhaps the one which deals with the care of premature babies would get our vote; but there are others which run it very close.
The Parents' Book : A Book which Answers ChILDren's Questions. By Rita Strauss, assisted by a Staff of Contributors. (London: T. C. and E. C. Jack. 1913. Pp. 750. Price 3s. 6d.)

A wonderfully cheap book and a reference library in itself. This is the impression which "The Parents' Book" leaves behind. We can imagine that those who have to deal with children will greet this publication with a sense of relief at the prospect that therein in numerable awkward posers will be solved. Answers are given to thousands of questions on every conceivable topic-indoors and outdoors-ships, railways, and other things that "go," telephones, history, zoology, physiology, and so on are all explained. The information is given in simple language and free from discursive detail, so that it may be easily remembered. There are about a dozen sections in which answers are grouped togetheran arrangement much more satisfactory than an interminable alphabetical series. In spite of the very large amount of material at the inquirer's command, no doubt some parents will still be "floored" even though they seek its pages, but this cannot detract from the opinion that this delightful encyclopædia is both a good investment and a source of lasting interest, even if it does not quite cover all the ground of a child's imagination or curiosity. 